\title{
The Implementation of Blended Learning in English Learning
}

\author{
Mahalli \\ Postgraduate of Universitas Negeri Semarang, Jl. Kelud Utara III Semarang 50237 \\ \{favimillati@gmail.com\}
}

\begin{abstract}
This research was conducted to analyze the implementation of blended learning. This study focused on the implementation of blended learning in academic writing course in English Education Study Program of UNISNU Jepara. The aim of this study is to describe how blended learning is implemented in the teaching and learning of writing subject in English Education Study Program. Observation on the implementation of blended learning in writing class was done 3 times. Station Rotation, consisting of three stations of learning; 1) teacher led instruction, 2) independent works or collaborative activity, and 3) online learning is blended learning model that is used in learning. The model is balanced in combining face-to-face and online learning.
\end{abstract}

Keywords: implementation, station rotation, blended learning, English learning

\section{INTRODUCTION}

Education that develops the ability, character and dignity of the nation as mentioned in the UUSPN No. 20/ 2003 should be implemented in an interactive, inspiring, fun and challenging to motivate students to actively participate and provide enough space for innovation, creativity and independence in accordance with their talents, interests and physical and psychological development of learners (PP 65/2013). Meanwhile, referring to PP 65 / 2013, learning process will be less interactive if it is not a process of interaction, both the interaction between educators and learners, learners with the media used, learners with other learners and learners with a classroom environment.

Relating with learning resources, there is not only printed material but also a wide range of technological resources such as the internet and technological devices used all over the world to complement Face-to-Face classes. There are virtual resources such as wilds, blogs, podcasts, emails, websites, video links, iPads, third screen devices, etc., which strengthen foreign language learning. Marsh (2012:1) stated that learning a foreign language presents different challenges for different people in different contexts. From this point of view, various methods and approaches should be used to introduce new language, and a variety of classroom management techniques are employed to maximize practice of teaching and learning. [1]

The initial data of the observation of the EFL teaching shows that the majority of foreign language teaching still takes place in the classroom, and as language teachers, we know from experience that achieving the optimum learning goal poses a significant challenge in most foreign language teaching situations where students have limited opportunities to actively engage in using the target language. 
As language teachers we understand that to serve the needs of our learners, we need to create an environment that most closely resembles actual use of the target language. "Advances in technology provide new opportunities for teachers to design and deliver their courses in ways that support and enhance the teachers' role, the students' individual cognitive experiences, as well as the social environment" (Bath and Bourke, 2010:1) [2].

The advent of new technologies has provided opportunities and challenges for education institutions to seek more effective ways of teaching and learning. Related with this condition, Rosenbaum (2012:5) claims that blended learning is now an established phenomenon in education, and institutions are increasing their effort to offer greater flexibility, more personalized learning, and greater learner satisfaction [3]. Dos (2014:122) stated that Blended learning is a combination of face-to-face learning and online learning. Both learning environments have unique features. One unique instructional feature of a face-to-face learning environment is that it provides direct, place-based, social interaction between students, the instructor and other students [4].

Blended learning is the new learning strategy implemented in higher education at UNISNU Jepara. As such a new strategy, it is very interesting to investigate how it is implemented in teaching and learning.

Based on the observation on the teaching and learning in this study program, the writer got the data that the implementation of blended learning in academic writing subject is more impressing and interesting than that in the teaching and learning of the other language skills. This insists the writer to investigate the implementation of blended learning strategy in the teaching and learning of academic writing subject.

\section{METHODOGY}

This study investigated some aspects of the implementation of blended learning strategy in teaching and learning of writing subject in English Education study program. They are; the plan, the modes, the models of integration, the distribution of learning content and objectives, the language teaching methods, the involvement of learning subjects, and the location. As it is a certain case happened in a certain subject or context, the same case may not happen to other subject or context, therefore, the study is categorized as a case study.

This study use a single-case design. The case is the implementation of blended learning in teaching and learning within a broader context of English lectures at an institution of higher education. The unit of analysis is the teaching and learning of academic writing.

The unit of analysis was carefully chosen to reflect purposeful sampling used in qualitative research because "we intentionally sample a group of people that can best inform the researcher about the research problems under examination" (Creswell, 2007: 118) [5]. . The choice of the unit of analysis was made based on certain consideration, that is the implementation of blended learning in teaching and learning of academic writing.

Those aspects will be investigated and evaluated by doing classroom observation of the implementation of blended learning model in teaching and learning academic writing.

The instrument used to observe the implementation of blended learning is adopted from Neumeier (2005) which covers: a) the plan of blended learning implementation; b) the models of integration; c) the distribution of learning content and objectives; d) the language teaching methods used in teaching reading and writing; e ) the involvement of learning subjects; f) the location where the process of teaching and learning takes place [6]. 


\section{FINDING AND DISCUSSION}

Table 1. First Observation Result

\begin{tabular}{|c|c|c|}
\hline No. & Object & Result \\
\hline & Main material & Characteristics of Academic Writing \\
\hline & Modes: & Face-to-face and online learning \\
\hline & $\begin{array}{l}\text { Models of } \\
\text { integration: }\end{array}$ & $\begin{array}{l}\text { Station rotation model: } \\
\text { Learning Steps } \\
\text { 1. Lecturer devided students into } 3 \text { groups; 1) Lecturer led } \\
\text { instruction (A), 2) on line instruction (B), 3) collaborative activities } \\
\text { and stations (C). } \\
\text { 2. Lecturer devided the time allocation for each group to do activities } \\
\text { in } 30 \text { minutes, they are: } \\
\text { 3. First circle (first } 30 \text { minutes) } \\
\text { In } 30 \text { minutes group A joined lecturer based learning. Lecturer } \\
\text { explained the main format and structure of academic writing. Group } \\
\text { B did online activity by internet browsing related to the topic of } \\
\text { learning in } 30 \text { minutes. They opened.. com/academic-writing/ } \\
\text { characteristics -academic- writing.. (characteristic of academic } \\
\text { writing) } \\
\text { At the same time group C discussed about learning topic } \\
\text { (characteristic of academic writing) } \\
\text { 4. Second circle (second } 30 \text { minutes) } \\
\text { In } 30 \text { minutes group C discussed about the result of group discussion } \\
\text { guided by the lecturer. Group B did on line activity by internet } \\
\text { browsing related to the topic of learning in } 30 \text { minutes. They } \\
\text { opened.. https://www.gcu.ac.uk/ gsbs/ldc/ academic writing/ } \\
\text { improveyour academicwriting/ characteristics } \\
\text { ofacademicwriting } \\
\text { At the same time group A discussed about learning topic } \\
\text { 5. Third circle (third } 30 \text { minutes) } \\
\text { In } 30 \text { minutes group B discussed about the result of group discussion } \\
\text { guided by the lecturer. } \\
\text { Group A did on line activity by internet browsing related to the topic } \\
\text { of learning in } \quad 30 \quad \text { minutes. } \\
\text { https://www.rlf.org.uk/resources/academic-writing-key-features/ } \\
\text { At the same time group B discussed about learning topic } \\
\text { 6. At the end of the activity, the lecturer confirmed and clarified } \\
\text { things related to the topic of learning that already discussed with } \\
\text { online and offline meeting as well. }\end{array}$ \\
\hline & $\begin{array}{l}\text { Distribution of } \\
\text { learning content and } \\
\text { objectives and } \\
\text { assignment of } \\
\text { purpose: }\end{array}$ & $\begin{array}{l}\text { Learning is done parallely between face to face and online learning } \\
\text { at the same time in the class. }\end{array}$ \\
\hline & Methods of ELT: & Collaborative learning: Presentation, group discussion \\
\hline
\end{tabular}




\begin{tabular}{|l|l|l|}
\hline & $\begin{array}{l}\text { Involvement of } \\
\text { learning subjects } \\
\text { (student, teacher, } \\
\text { computer): }\end{array}$ & $\begin{array}{l}\text { In this learning activity, there are 3 supported components. } \\
\text { Lecturer as facilitator and source, students as active learner and } \\
\text { supported by computer, iPad and smart phone. } \\
\text { In this activity, students got aoutonomy in learning. }\end{array}$ \\
\hline Location: & In the classroom/ leraning centre. \\
\hline
\end{tabular}

Table 2. Second Observation Result

\begin{tabular}{|c|c|c|}
\hline No. & Object & Result \\
\hline & Main material & $\begin{array}{l}\text { Appropriate ways of writing statements (distancing devices, } \\
\text { passive and active voice) }\end{array}$ \\
\hline & Modes: & Face-to-face and online learning \\
\hline & $\begin{array}{l}\text { Models of } \\
\text { integration: }\end{array}$ & $\begin{array}{l}\text { Station rotation model: } \\
\text { Learning Steps } \\
\text { 1. Lecturer devided students into } 3 \text { groups. 1) Lecturer led } \\
\text { instruction (A), 2) on line instruction (B), 3) collaborative activities } \\
\text { and stations (C). } \\
\text { 2. Lecturer devided the time allocation for each group to do } \\
\text { activities in } 30 \text { minutes, they are: } \\
\text { 3. First circle (first } 30 \text { minutes) } \\
\text { In } 30 \text { minutes group A joined lecturer based learning with topic } \\
\text { Appropriate ways of writing statements ; distancing devices, passive } \\
\text { and active voice, the use of "I"). } \\
\text { Group B did online activity by internet browsing related to the topic } \\
\text { of learning (Appropriate ways of writing statements ; distancing } \\
\text { devices, passive and active voice, the use of "I") in } 30 \text { minutes by } \\
\text { opening website. } \\
\text { At the same time group C discussed about learning topic } \\
\text { (Appropriate ways of writing statements;distancing devices, passive } \\
\text { and active voice, the use of "I") } \\
\text { 4. Second circle (second } 30 \text { minutes) } \\
\text { In } 30 \text { minutes group C discussed about the result of group discussion } \\
\text { guided by the lecturer. In order to get deeper understanding about } \\
\text { the topic, group B did on line activity by internet browsing related } \\
\text { to the topic of learning in } 30 \text { minutes. They opened. } \\
\text { https://www.princetonreview.com/grad-school-advice/statement- } \\
\text { of-purpose. } \\
\text { At the same time group A discussed about learning topic } \\
\text { 5. Third circle (third } 30 \text { minutes) } \\
\text { In } 30 \text { minutes group B discussed about the result of group discussion } \\
\text { guided by the lecturer. } \\
\text { Group C did on line activity by internet browsing related to the topic } \\
\text { of learning in } 30 \text { minutes. They opened.. academic-writing/ } \\
\text { resources/good- academic writing } \\
\text { At the same time group A discussed about learning topi } \\
\text { and }\end{array}$ \\
\hline
\end{tabular}




\begin{tabular}{|l|l|l|}
\hline & $\begin{array}{l}\text { 6. At the end of the activity, the lecturer confirmed and clarified } \\
\text { things related to the topic of learning that already discussed with } \\
\text { online and offline meeting as well. }\end{array}$ \\
\hline & $\begin{array}{l}\text { Distribution of } \\
\text { learning content and } \\
\text { objectives and } \\
\text { assignment of } \\
\text { purpose: }\end{array}$ & $\begin{array}{l}\text { Learning is done parallely between face to face and online learning } \\
\text { at the same time in the class. }\end{array}$ \\
\hline Methods of ELT: & $\begin{array}{l}\text { Collaborative learning: Presentation, group discussion } \\
\text { learning subjects } \\
\text { (student, teacher, } \\
\text { computer): }\end{array}$ & $\begin{array}{l}\text { There are } 3 \text { upported components in this session of learning. } \\
\text { Lecturer as facilitator and source, students as active learner and } \\
\text { supported by computer, iPad and smart phone. } \\
\text { In this activity, students got aoutonomy in learning. }\end{array}$ \\
\hline Location: & In the classroom/ learning center. \\
\hline
\end{tabular}

Table 3. Third Observation Result

\begin{tabular}{|c|c|c|}
\hline No. & Object & 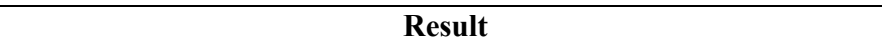 \\
\hline & Main material & Paraphrasing (convention and explanation) \\
\hline & Modes: & Face-to-face and online learning \\
\hline & $\begin{array}{l}\text { Models of } \\
\text { integration: }\end{array}$ & $\begin{array}{l}\text { Station rotation model: } \\
\text { Learning Steps } \\
\text { 1. Lecturer devided students into } 3 \text { groups. 1) Lecturer led instruction } \\
\text { (A), 2) on line instruction (B), 3) collaborative activities and stations } \\
\text { (C). Each group consisted of } 10-11 \text { students. } \\
\text { 2. Lecturer devided the time allocation for each group to do activities } \\
\text { in } 30 \text { minutes, they are: } \\
\text { 3. First circle (first } 30 \text { minutes) } \\
\text { In } 30 \text { minutes group A joined lecturer based learning with topic (how } \\
\text { to apply the rules of paraphrasing in writing) } \\
\text { Group B did online activity by internet browsing related to the topic } \\
\text { of learning (how to apply the rules of paraphrasing in writing) in } 30 \\
\text { minutes by opening https://writingcenter.unc. edu/esl/resources/ } \\
\text { writing-paraphrases } \\
\text { At the same time group C discussed about the learning topic (how to } \\
\text { apply the rules of paraphrasing in writing) } \\
\text { 4. Second circle (second } 30 \text { minutes) } \\
\text { In } 30 \text { minutes group B discussed about the result of group discussion } \\
\text { guided by the lecturer. Group C did online activity by internet } \\
\text { browsing related to the topic of learning in } 30 \text { minutes. At the same } \\
\text { time group A discussed about the learning topic } \\
\text { 5. Third circle (third } 30 \text { minutes) } \\
\text { In } 30 \text { minutes group C discussed about the result of group discussion } \\
\text { guided by the lecturer. } \\
\text { Group A did on line activity by internet browsing related to the topic } \\
\text { of learning in } \quad 30 \quad \text { minutes. } \\
\text { https://lo.unisa.edu.au/mod/book/view.php?id= } \\
\text { 25214 opened.. } \\
\text { At the same time group B discussed about learning topi }\end{array}$ \\
\hline
\end{tabular}




\begin{tabular}{|l|l|l|}
\hline & $\begin{array}{l}\text { 6. At the end of the activity, the lecturer confirmed and clarified things } \\
\text { related to the topic of learning that already discussed with online and } \\
\text { offline meeting as well. }\end{array}$ \\
\hline $\begin{array}{l}\text { Distribution of } \\
\text { learning content } \\
\text { and objectives and } \\
\text { assignment of } \\
\text { purpose: }\end{array}$ & $\begin{array}{l}\text { Learning is done parallely between face to face and online learning at } \\
\text { the same time in the class. }\end{array}$ \\
\hline & $\begin{array}{l}\text { Methods of ELT: } \\
\text { learning subjects } \\
\text { (student, teacher, } \\
\text { computer): }\end{array}$ & $\begin{array}{l}\text { Collaborative learning: Presentation, group discussion } \\
\text { as facilitator and source, students as active learner and supported by } \\
\text { computer, iPad and smart phone. } \\
\text { In this activity, students got aoutonomy in learning. }\end{array}$ \\
\hline Location: & In the classroom/ learning center. \\
\hline
\end{tabular}

Based on the observation table, resulted from the three observations done by the researcher, blended learning which was implemented in teaching and learning of academic writing course, covers;1) the modes of integration is face-to-face and online learning, 2) the model of integration is Station Rotation model, 3) Distribution of learning content and objectives and assignment of purpose is done in both face to face and online learning at the same time in the class, 4) the language teaching methods used in teaching reading is methods of ELT consist of collaborative learning, presentation and group discussion, 5) Three supported components; lecturer as facilitator and source, students as active learner and supported by computer, iPad and smart phone are involved in the learning process. In this activity, students got autonomy in learning, 6) the location where the process of teaching and learning takes place in the classroom/ learning center; 7) the evaluation of blended learning implementation is by assessing the process.

Station rotation model of blended learning is implemented in class by dividing students into 3 groups, with 3 stages: 1) teacher led instruction (Group A), 2) on line instruction (B), 3) collaborative activities and stations $(\mathrm{C})$.

The lecturer divides the time allocation for each group to carry out activities for 30 minutes with the following activities:

First round (first 30 minutes) Group A conducts guided learning activities by the lecturer. Lecturers explain the outline of the material. Group B conducts online activities by browsing the internet related to lecture material which is the topic of lectures for 30 minutes by opening the web. At the same time group $\mathrm{C}$ conducts discussions discussing the lecture topics being taught.

Second round (second 30 minutes) During 30 minutes group C conducted discussion activities about the results of group discussion sessions guided by lecturers. Group B conducts online activities by browsing the internet related to lecture material which is the topic of lectures for 30 minutes by opening the web. At the same time group A carried out a discussion about the topic of the lecture being taught.

Third round (third 30 minutes). During 30 minutes group B conducted a discussion about the results of the online session which was guided by lecturers, group A conducted online activities by browsing the internet related to lecture material which was the topic of lectures for 30 minutes, by opening the web. At the same time group $\mathrm{C}$ held an off line discussion discussing the topic of the lecture being taught. At the end of the activity the lecturer provides confirmation 
and clarification related to the topic of the lecture that has been discussed both through on line and through off line discussions.

This condition shows that the implementation of blended learning that has been carried out in Academic Writing in English Language Education study program (PBI), Unisnu Jepara is linear with the opinion of Staker and Horn (2012: 8) of the four models of blended learning. One of them - station rotation model - has been implemented in teaching and learning Academic Writing courses[7]. It is also in line with the opinion of Lee and Lee (2007: 149) that the blended learning design for language education, prefer to mix the two parts are relatively equally (named balanced face-to-face and online class) [8].

\section{CONCLUSION}

Based on the findings and discussion about the implementation of blended learning in Academic Writing course of English Education Study Program of Unisnu Jepara, it can be concluded that Station Rotation model was used in the implementation of blended learning in Academic Writing subject in which the class was devided into three station of learning; 1) teacher led instruction, 2) independent works or collaborative activity, and 3) online learning. The blended learning design for language education, in this study prefer to mix the two parts relatively equal, namely balanced face-to-face learning and online learning.

\section{Acknowledgments}

This research was supported by the head of English Education Study Program of Unisnu Jepara, who has given me permission to conduct the research. I would also like to show my gratitude to Mr. Muhlas Yusak, the lecturer of Academic Writing and Blended Learnins courses for his precious insight and expertise that actually assisted the completion of the Article.

\section{References}

[1] D. Marsh, "Blended Learning, Creating Learning Oportunities for Language Learners," Cambridge University Press, 2012.

[2] D. Bath and J. Bourke, "Getting Started with Blended Learning," Griffith Institute for Higher Education, 2010.

[3] P. Rosenbaum, "E-Learning; A study of students' attitudes and learning outcome when using blended learning with integration of multimedia instructions," Dissertation for the degree philosophy doctor (PhD) at the University of Bergen, 2012.

[4] B. Dos, "Developing And Evaluating a Blended Learning Course," Faculty of Education, Zirve University, Turkey, 2014.

[5] J.W. Creswell, "Research Design: Qualitative and Quantitative Approaches," Sage, 1994.

[6] Neumeier, P. 2005 'A Closer Look at Blended Learning-Parameters for Designing a blended learning Environment for Language Teaching and Learning, Cambridge University Press: ReCALL, 17(2), 163-178. Rertieved 9 Maret 2014 from https://www.researchgate.net/.../231873580

[7] S. Heather and B. Horn, "Classifying K-12 Blended learning," Sight Institute., pp. 8-11, 2012

[8] S.H. Lee and J.H. Lee, "Blended Learning Revisited; A New Approach to Foreign Language Education," Indiana University. 2007. 
